\title{
FEED MICROBIAL CONTAMINATION IN PIG-BREEDING: MODERN THREATS AND WAYS TO OVERCOME THEM
}

\author{
Kolchyk O. V., Buzun A. I. \\ National Scientific Center 'Institute of Experimental and Clinical Veterinary \\ Medicine’, Kharkiv, Ukraine; e-mail: kolchyk-elena@ukr.net, epibuz@ukr.net
}

\begin{abstract}
Summary. The paper presents the results on the species and percentage composition of the microflora in biofilms of pig feed, which varies depending on the seasonal factor. Bacteria Streptococcus spp., Pasteurella multocida, Neisseria spp., and Clostridium perfringens in biofilms were found much more often (by $25 \%$ or more) in the warm period of the year, while listeria in silage and haylage - in the autumn-winter period. This property of feed biofilms is also significantly influenced by the conditions of cultivation, harvesting and storage of agricultural products. In the study of biofilms of microflora of barley, corn and wheat, it was found that their structural basis are aerobic fungi of the mold Aspergillus spp. Bacteria Streptococcus spp., Pasteurella multocida, Neisseria spp., and Clostridium perfringens without mold form much looser biofilms in vitro and these biofilms are much more sensitive to a wide range of commercial antibiotics. The structural basis of polymicrobial biofilms of barley, corn and wheat microflora is highly likely to be aerobic fungi of Aspergillus spp.
\end{abstract}

Keywords: bacterial biofilms, fodder crops, veterinary and sanitary quality of fodder, listeria, pasteurellosis, clostridiosis

Introduction. Problems of microbial (fungalbacterial-viral) contamination of feed and equipment critically affect the productivity of industrial livestock. Therefore, in the EU livestock industry, in accordance with the requirements of the 'GMP+' standard, fodder is inspected at all stages of its production - and even more strictly than food. After all, it is believed that the cost of maintaining fodder biosafety is disproportionately lower than the diagnosis and treatment of animals, and then people as consumers of livestock products (Roy et al., 2018). In Ukraine, this attitude to fodder production at the state level, unfortunately, is only beginning to emerge.

It is scientifically proven that the veterinary and sanitary condition of feed is determined by the level of microbial contamination of raw materials (and hence fodder-producing areas!), as well as its contamination in the process of fodder production and during storage of finished feed. It is no secret that today for the production of feed 'residual grain' (practically, grain waste) is often used, and even raw materials from technical ('energy') crops, containing a special microflora - primarily clostridia, which synthesize biofuels (Bajracharya et al., 2016).

In addition, under conditions of heat treatment (extrusion, etc.), crops such as vetch and some others emit hydrocyanic acid (Rybachenko, 2011). Feeds contaminated with microflora not only quickly lose their nutritional value due to bacterial and fungal activity, but they pose a serious threat to pig health. A special threat is the entry into the feed of pathogens of devastation diseases and anthropozoonoses: during transportation, storage or even at the stage of growing forage crops.

Virulent variants of Clostridium perfringens, Neisseria spp., Pasteurella multocida, and Actinobacillus pleuropneumonia, which cause acute pneumoenteritis in piglets and chronic infections in older pigs, pose a significant risk to pig health (Pace, Rupp and Finch, 2005; Dalili et al., 2015; Meena and Kanwar, 2015).

These microorganisms are not included in the updated 'List of maximum permissible levels of undesirable substances in feed and feed materials for animals' (MAPFU, 2012), but according to our own research since 2010 we have noted the presence of bacteria associations in feed for pigs, and in 2016-2019, using laboratory methods for the study of bacterial biofilms, we have concluded that their presence in feed for pigs is regular.

This paper is an attempt to experimentally and theoretically substantiate this pattern, which, in our opinion, is insufficiently studied and is essential for the biosafety of pig breeding in Ukraine.

The aim is to study the species composition of microflora in biofilms of pig feed depending on the seasonal factor.

Materials and methods. Bacteriological studies of feeds were performed according to generally accepted methods in Ukraine (MAPFU, 2012), as well as by experimental methods for the study of bacterial biofilms (Oggioni et al., 2006). Sampling and delivery of feed samples (barley, oats, corn, wheat, grits, prestarter, etc.) from 18 pig farms in 5 regions of Ukraine and their veterinary and sanitary assessment was carried out according to the order of the Ministry of Agrarian Policy and Food of Ukraine No. 131 of 19.03.2012, and, simultaneously, following the developed experimental approaches and the obtained experimental-analytical data. In particular, for the destruction of forage biofilms and the subsequent isolation of target bacteria (Clostridium perfringens, Neisseria spp., Pasteurella 
multocida, and Actinobacillus pleuropneumonia) we used sterilized by filtration eluent, the composition of which is being patented.

Isolation, cultivation, and study of cultural and morphological properties of feed microorganisms were performed on nutrient media: meat peptone broth (MPB, pH 7.2-7.4), Hottinger broth, Martin's medium, $2.5 \%$ MPB with the addition of $2 \%$ glucose or selective Fraser additive (for isolation of listeria), meat peptone agar (MPA, pH 7.2-7.4), Endo agar, modified Kita-Tarotzi medium, MGM-4 medium, Blauroca, Saburo agar, Olkenitsky medium, Simons citrate, acetate agar, PALCAM agar (for identification of listeria), MuellerHinton agar for disco-diffusion test (DDT). The ability of bacterial isolates to form biofilms was studied by the micromethod (O'Toole, 2011). Antibiotic resistance and the ability of isolated bacterial isolates to form biofilms were studied by modern experimental methods (MHU, 2007; Oggioni et al., 2006).

Pathogenicity of isolated field isolates of bacteria was tested on white mice (weighing 16-18 g) by intraabdominal infection at a dose of $0.5 \times 10^{9}$ bacterial cells in accordance with the requirements of the Law of Ukraine No. 3447-IV from 21.02.2006 'About protection of animals from cruel treatment' (VRU, 2006), the 'European Convention for the Protection of Vertebrate Animals Used for Experimental and Other Scientific Purposes' (CE, 1986), and Council Directive 86/609/EEC (CEC, 1986). Ethyl ether was used for anesthesia.

Results and discussions. In the period 2016-2019, 220 samples of animal feed were examined for the presence of film-forming and planktonic forms (freefloating cells) of opportunistic microflora (including 34 samples of silage and haylage for dairy cattle regarding the risk of listeriosis in pig breeding through skim for piglets), and the rest - feeds and their grain ingredients for pig breeding) in 18 farms (crop with livestock including pig breeding or pig breeding with livestock, both cattle and small cattle) in 5 regions: Kharkiv $(\mathrm{n}=4)$, Sumy $(\mathrm{n}=4)$, Kherson $(\mathrm{n}=4)$, Poltava $(\mathrm{n}=4)$, and Vinnytsia $(\mathrm{n}=2)$. These areas were selected because of their ecogeographical distribution in terms of soil moisture - one of the most important factors in the survival of opportunistic pathogens in the environment, in particular on forage lands.

Common features of the surveyed farms, in addition to the multidisciplinary nature typical of modern agriculture in Ukraine, were also the conditions of their location in the range of soil moisture from 125 to $175 \mathrm{~mm}$, the share of cereals of their own origin at least $75 \%$ in the diet of pigs and use of pig manure for growing their own fodder crops.

Table 1 shows that opportunistic pathogens, as a component of bacterial and fungal biofilms, were found in almost all samples of the surveyed farms. The bioassay with the obtained isolates $(n=75)$ was negative (none of them caused the death of mice within 10 days after infection, although there were some signs of deterioration in the health of experimental mice during the first 3-4 days).

At the same time, in the nasal smears of pigs $(\mathrm{n}=49)$, almost all examined, we found pasteurella of those serotypes that were found in the feed in these farms, and 32 of their isolates $(65.3 \%, \mathrm{P}<0.01$; isolates both from clinically sick and healthy pigs) were virulent in mice. Clostridia isolated from rectal smears $(n=27)$ of clinically sick piglets $(n=12)$ were virulent for mice, and clostridia isolated from sows with healthy nests $(n=15)$ were avirulent for mice.

In our opinion, the obtained data indicate a direct connection between the epizootic process of pasteurellosis and anaerobic enterotoxemia in pig farming with contamination of feed (and hence the environment) with biofilms with the corresponding opportunistic microflora. In turn, this may be a consequence of the widespread use in crop production of the surveyed farms insufficiently decontaminated pig manure.

As shown in Table 1, the composition of biofilms containing the studied opportunistic microflora differed significantly between samples of cereals of different species. Its greatest diversity ( 4 or more studied species of microorganisms) in all farms was registered in samples of barley grain and, accordingly, in bran and feed mixtures with its content (Streptococcus spp., Pasteurella multocida, Aspergillus niger, Neisseria spp., Clostridium perfringens), the least - in wheat samples (Pasteurella multocida, Aspergillus niger).

In the sample of litter from straw waste for cattle in one of the pig farms in Sumy Region we detected by laboratory methods biofilm of 8 species of opportunistic pathogens, including spirochete: at the time of the survey at a fattening site $7 \mathrm{~km}$ away from the pig farm, cattle leptospirosis was registered with abortions and stillbirths of calves.

Mycoplasmas were often sown (39-58\% of the studied samples from different farms) together with Pasteurella multocida, Clostridia, and Neisseria from biofilms of prestarter feed samples from different producers $(n=27)$. A characteristic feature of the circulation of industrially produced prestarter and other feed for pigs in these farms was virtually free access of synanthropic birds and rodents to places of their storage.

The results of a survey of two farms in Poltava and Vinnytsia regions regarding listeriosis need special consideration.

In Poltava Region, the diet of pigs and cattle for a number of years included grain and haylage from energy crops, which contain a specific 'biofuel' microflora of the so-called 'Clostridium complex of biofuels No. 1'. In Vinnytsia Region, the diet of pigs and cattle included potatoes with a high content of gossypol. 
Table 1 - Geographical and seasonal dynamics of dangerous for pigs microorganisms, which were found in the grain in surveyed farms and fodder of plant origin in 2016-2019

\begin{tabular}{|c|c|c|c|c|c|c|c|c|c|c|c|}
\hline \multirow{3}{*}{$\begin{array}{c}\text { Type of } \\
\text { feed, } \\
\text { fodder } \\
\text { ingredients }\end{array}$} & \multirow{3}{*}{$\begin{array}{l}\text { Species of isolated potentially } \\
\text { dangerous microflora }\end{array}$} & \multicolumn{10}{|c|}{$\begin{array}{l}\text { Percentage of positive samples from the farms (n) } \\
\text { in spring-summer (A) and autumn-winter (B) seasons }\end{array}$} \\
\hline & & \multicolumn{2}{|c|}{$\begin{array}{c}\text { Kharkiv, } \\
\mathrm{n}=4\end{array}$} & \multicolumn{2}{|c|}{$\begin{array}{c}\text { Sumy, } \\
\mathrm{n}=4\end{array}$} & \multicolumn{2}{|c|}{$\begin{array}{c}\text { Kherson, } \\
\mathrm{n}=4\end{array}$} & \multicolumn{2}{|c|}{$\begin{array}{c}\text { Poltava, } \\
\mathrm{n}=4\end{array}$} & \multicolumn{2}{|c|}{$\begin{array}{l}\text { Vinnytsia, } \\
\mathbf{n}=2\end{array}$} \\
\hline & & $\mathbf{A}$ & $\mathbf{B}$ & $\mathbf{A}$ & $\mathbf{B}$ & $\mathbf{A}$ & $\mathbf{B}$ & $\mathbf{A}$ & $\mathbf{B}$ & $\mathbf{A}$ & $\mathbf{B}$ \\
\hline \multirow{5}{*}{$\begin{array}{l}\text { Barley } \\
(\mathrm{n}=28)\end{array}$} & Streptococcus spp. & 62 & 38 & 57 & 43 & 65 & 35 & 52 & 48 & 69 & 31 \\
\hline & Pasteurella multocida serotype D & 54 & 46 & 55 & 45 & 58 & 42 & 46 & 50 & 51 & 40 \\
\hline & Aspergillus niger & 73 & 27 & 78 & 22 & 66 & 34 & 75 & 25 & 64 & 36 \\
\hline & Neisseria spp. & 52 & 48 & 50 & 50 & 57 & 43 & 55 & 45 & 49 & 51 \\
\hline & Clostridium perfringens & 23 & 77 & 26 & 74 & 29 & 71 & 32 & 68 & 21 & 79 \\
\hline \multirow{3}{*}{$\begin{array}{l}\text { Corn } \\
(\mathrm{n}=21)\end{array}$} & Aspergillus niger & 65 & 35 & 68 & 32 & 72 & 28 & 67 & 33 & 74 & 26 \\
\hline & Streptococcus spp. & 51 & 49 & 56 & 44 & 53 & 47 & 48 & 52 & 59 & 41 \\
\hline & Candida albicans & 48 & 52 & 46 & 54 & 57 & 43 & 62 & 38 & 65 & 35 \\
\hline \multirow{3}{*}{ Oat $(\mathrm{n}=26)$} & Pasteurella multocida serotypes A and D & 41 & 59 & 47 & 53 & 42 & 58 & 56 & 44 & 54 & 46 \\
\hline & Staphylococcus aureus & 73 & 27 & 71 & 29 & 68 & 32 & 65 & 35 & 62 & 38 \\
\hline & Clostridium perfringens & 33 & 67 & 28 & 72 & 31 & 69 & 25 & 75 & 38 & 62 \\
\hline \multirow{2}{*}{$\begin{array}{l}\text { Wheat } \\
(\mathrm{n}=24)\end{array}$} & Pasteurella multocida serotype A & 45 & 55 & 48 & 52 & 53 & 47 & 56 & 44 & 59 & 41 \\
\hline & Aspergillus niger & 70 & 30 & 74 & 26 & 78 & 22 & 67 & 33 & 77 & 23 \\
\hline \multirow{5}{*}{$\begin{array}{c}\text { Bran } \\
(\mathrm{n}=25)\end{array}$} & Mycoplasma spp. & 63 & 37 & 65 & 35 & 56 & 44 & 62 & 38 & 58 & 42 \\
\hline & Pasteurella multocida serotype D & 43 & 57 & 46 & 54 & 51 & 49 & 55 & 45 & 57 & 43 \\
\hline & Aspergillus niger & 69 & 31 & 73 & 27 & 77 & 23 & 79 & 21 & 66 & 34 \\
\hline & Neisseria spp & 57 & 43 & 54 & 46 & 55 & 45 & 51 & 49 & 48 & 52 \\
\hline & Clostridium perfringens & 14 & 86 & 11 & 89 & 22 & 78 & 17 & 83 & 23 & 77 \\
\hline \multirow{4}{*}{$\begin{array}{c}\text { Bran com- } \\
\text { pound feed } \\
\text { mixtures } \\
(\mathrm{n}=35)\end{array}$} & Pasteurella multocida serotype D & 56 & 44 & 61 & 39 & 58 & 42 & 48 & 52 & 63 & 37 \\
\hline & Mycoplasma hyopneumonia & 25 & 75 & 20 & 80 & 22 & 78 & 19 & 81 & 23 & 77 \\
\hline & Clostridium difficile & 31 & 69 & 36 & 64 & 33 & 67 & 28 & 72 & 26 & 74 \\
\hline & Clostridium botulinum & 17 & 83 & 15 & 85 & 13 & 87 & 19 & 81 & 12 & 88 \\
\hline \multirow{2}{*}{$\begin{array}{l}\text { Prestarter } \\
(\mathrm{n}=27)\end{array}$} & Pasteurella multocida serotypes A and D & 57 & 43 & 51 & 49 & 45 & 55 & 58 & 42 & 61 & 39 \\
\hline & Neisseria spp. & 64 & 36 & 58 & 42 & 56 & 44 & 61 & 39 & 60 & 40 \\
\hline \multirow{3}{*}{$\begin{array}{l}\text { Silage and } \\
\text { haylage** } \\
(\mathrm{n}=34)\end{array}$} & Neisseria spp. & 47 & 53 & 42 & 58 & 49 & 51 & 46 & 54 & 54 & 46 \\
\hline & Pasteurella multocida serotype D & 52 & 48 & 56 & 44 & 51 & 49 & 47 & 53 & 55 & 45 \\
\hline & Listeria monocytogenes & 0 & 16 & 0 & 12 & 0 & 0 & 0 & 45 & 0 & 73 \\
\hline
\end{tabular}

Notes: ${ }^{*}$-isolated microflora was avirulent for mice-albino; ${ }^{* *}$ - pigs + cattle, etc.

Therefore, a certain period of time 'humpback' and paresis in pigs, sow agalactia and subclinical mastitis of cows, as well as swine neuroinfection and reproductive disorders in cattle in Vinnytsia Region were associated with feed and genetic factors. However, the isolation of Listeria monocytogenes from silage samples in both farms, as well as from the spinal cord and intestinal lymph nodes of young pigs, respectively, indicates the leading role of listeria in combination with clostridia in taking root enzootic associated infections in pigs in these farms.

Also from the data in Table 1 it is seen that the species and percentage composition of the microflora in the biofilms of feed for pigs varies depending on the seasonal factor. Bacteria Streptococcus spp., Pasteurella multocida, Neisseria spp., and Clostridium perfringens in these biofilms were found much more often (by $25 \%$ or more) in the warm period of the year, while listeria in the silage and haylage - in the autumn-winter period.

In our opinion, this property of feed biofilms is also significantly influenced by the conditions of cultivation, harvesting and storage of agricultural products. In the study of biofilms of the microflora of barley, corn and wheat, it was found that their structural basis ('framework') are aerobic fungi of the mold Aspergillus spp.

Without mold bacteria Streptococcus spp., Pasteurella multocida, Neisseria spp., and Clostridium perfringens form much looser biofilms in vitro, which disintegrate rapidly even with light shaking and are much more sensitive to a wide range of commercial antibiotics.

At the same time, according to the literature for the growth of mold in the soil and feed, especially in grain 
processing products, higher humidity required: at humidity below $13 \%$ and at $27-40^{\circ} \mathrm{C}$ fungi do not grow (Abraskova, Shashko and Shashko, 2013). That is, according to soil moisture indicators, the surveyed farms were in the risk zone of fungal contamination, and, accordingly, the formation of fungal-bacterial biofilms dangerous for pig breeding.

Conclusions. 1. According to the results of studies of 220 feed samples in the period 2016-2019 for the presence of film-forming and planktonic forms of opportunistic pathogenic microflora, a direct connection has been established between the epizootic situation in pig farming and contamination of feed with microorganisms capable of forming bacterial biofilms containing pathogens of pasteurellosis and anaerobic enterotoxemia.

2. The greatest diversity of opportunistic microflora (4 or more studied species of microorganisms) was found in samples of barley grain and, accordingly, in the bran and feed mixtures with its content (Streptococcus spp., Pasteurella multocida, Aspergillus niger, Neisseria spp., Clostridium perfringens), the least - in samples of wheat grain (Pasteurella multocida, Aspergillus niger).

3. Species and percentage composition of microflora in biofilms of pig feed varies depending on the seasonal factor. Bacteria Streptococcus spp., Pasteurella multocida, Neisseria spp., and Clostridium perfringens in these biofilms were found much more often (by $25 \%$ or more) in the warm period of the year, while listeria in silage and haylage - in the autumn-winter period.

4. Contamination of silage and haylage by listeria from $16 \%$ to $72 \%$ in four regions of Ukraine was registered in the autumn-winter season, which poses a direct danger to of multidisciplinary pig farms and human health.

5. The structural basis of polymicrobial biofilms of microflora of barley, corn and wheat with high probability are aerobic fungi of Aspergillus spp.

\section{References}

Abraskova, S. V., Shashko, Yu. K. and Shashko, M. N. (2013) Biological Safety of Feed [Biologicheskaya bezopasnost' kormov]. Minsk: Belarusnavuka. ISBN 9789850816146. [in Russian].

Bajracharya, S., Sharma, M., Mohanakrishna, G., Dominguez Benneton, X., Strik, D. P. B. T. B., Sarma, P. M. and Pant, D. (2016) 'An overview on emerging bioelectrochemical systems (BESs): Technology for sustainable electricity, waste remediation, resource recovery, chemical production and beyond', Renewable Energy, 98, pp.153-170. doi: 10.1016/j. renene.2016.03.002.

CE (The Council of Europe). (1986) European Convention for the Protection of Vertebrate Animals Used for Experimental and Other Scientific Purposes. (European Treaty Series, No. 123). Strasbourg: The Council of Europe. Available at: https:// conventions.coe.int/treaty/en/treaties/html/123.htm.

CEC (The Council of the European Communities). (1986) 'Council Directive 86/609/EEC of 24 November 1986 on the approximation of laws, regulations and administrative provisions of the Member States regarding the protection of animals used for experimental and other scientific purposes', The Official Journal of the European Communities, L 358, pp. 1-28. Available at: http://data.europa.eu/eli/dir/1986/609/oj.

Dalili, D., Amini, M., Faramarzi, M. A., Fazeli, M. R., Khoshayand, M. R. and Samadi, N. (2015) 'Isolation and structural characterization of Coryxin, a novel cyclic lipopeptide from Corynebacterium xerosis NS5 having emulsifying and antibiofilm activity', Colloids and Surfaces B: Biointerfaces, 135, pp. 425-432. doi: 10.1016/j.colsurfb.2015.07.005.

MAPFU (Ministry of Agrarian Policy and Food of Ukraine). (2012) On Approval of the List of Maximum Permissible Levels of Undesirable Substances in Feed and Feed Materials for Animals [Pro zatverdzhennia Pereliku maksymalno dopustymykh rivniv nebazhanykh rechovyn u kormakh ta kormovii syrovyni dlia tvaryn] (decree No. 131, 19.03.2012). Available at: https://zakon. rada.gov.ua/laws/z0503-12. [in Ukrainian].

Meena, K. R. and Kanwar, S. S. (2015) 'Lipopeptides as the antifungal and antibacterial agents: Applications in food safety and therapeutics', BioMed Research International, 2015, p. 473050 . doi: $10.1155 / 2015 / 473050$.

MHU (Ministry of Health of Ukraine). (2007) On Approval of the Methodological Guidelines 'Determination of the Sensitivity of Microorganisms to Antibacterial Drugs' [Pro zatverdzhennia metodychnykh vkazivok 'Vyznachennia chutlyvosti mikroorhanizmiv do antybakterialnykh preparativ'] (decree No. 167, 05.04.2007). Available at: https://zakon.rada.gov.ua/ $\mathrm{rada} / \mathrm{v} 0167282-07$. [in Ukrainian].

O'Toole, G. A. (2011) 'Microtiter dish biofilm formation assay', Journal of Visualized Experiments, 47, p. 2437. doi: $10.3791 / 2437$.

Oggioni, M. R., Trappetti, C., Kadioglu, A., Cassone, M., Iannelli, F., Ricci, S., Andrew, P. W. and Pozzi, G. (2006) 'Switch from planktonic to sessile life: A major event in pneumococcal pathogenesis', Molecular Microbiology, 61(5), pp. 1196-1210. doi: $10.1111 /$ j.1365-2958.2006.05310.x.

Pace, J. L., Rupp, M. E. and Finch, R. G. (eds.) (2005) Biofilms, Infection, and Antimicrobial Therapy. Boca Raton: CRC Press. doi: 10.1201/9781420028232.

Roy, R., Tiwari, M., Donelli, G. and Tiwari, V. (2018) 'Strategies for combating bacterial biofilms: A focus on antibiofilm agents and their mechanisms of action', Virulence, 9(1), pp. 522-554. doi: 10.1080/21505594.2017.1313372.

Rybachenko, O. M. (2011) 'The main problems of feed production in Ukraine' [Osnovni problemy rozvytku kormovyrobnytstva v Ukraini], AgroInKom, 10-12, pp. 34-37. Available at: http://www.iae.org.ua/images/aik/AgroInKom_ 2011_10-12.pdf. [in Ukrainian].

VRU (Verkhovna Rada Ukrainy) (2006) 'Law of Ukraine No. 3447-IV from 21.02.2006 "About protection of animals from cruel treatment” [Zakon Ukrainy № 3447-IV vid 21.02.2006 "Pro zakhyst tvaryn vid zhorstokoho povodzhennia"], News of the Verkhovna Rada of Ukraine [Vidomosti Verkhovnoi Rady Ukrainy], 27, art. 230. Available at: https://zakon.rada.gov.ua/laws/3447-15. [in Ukrainian]. 